\title{
Discretionary Governance
}

\section{Selection, Secrecy, and Status within the World Economic Forum}

\author{
Christina Garsten | ORCID: 0000-0002-1652-631X \\ Swedish Collegium for Advanced Study, Uppsala, Sweden; Department \\ of Social Anthropology, Stockholm University, Stockholm, Sweden \\ christina.garsten@swedishcollegium.se
}

\begin{abstract}
Adrienne Sörbom | ORCID: 0000-0001-6797-3892
Department of Sociology, Stockholm University, Stockholm, Sweden; School of Social Sciences, Södertörn University, Stockholm, Sweden adrienne.sorbom@score.su.se
\end{abstract}

\begin{abstract}
Built on the exclusive funding of 1,00o large transnational corporations, the World Economic Forum is a not-for-profit Swiss foundation, aiming to shape the direction of globalization. Its events are characterized by low degrees of formality and transparency. Research on what this organization does is scarce. This article suggests the term discretionary governance to capture the precarious, yet existing, social order that the organization shapes. By discretionary governance, we mean a set of discreet practices based on the organization's judgement in ways that escape established democratic controls. Drawing on ethnographic data the paper demonstrates how selection, secrecy, and status form key components of this tenuous ordering. Selection processes and secrecy contribute to status elevation of the individuals and organizations chosen to participate. Upon them and the organization itself is bestowed a symbolic capital that is practical and possibly profitable in the world of global governance.
\end{abstract}

\section{Keywords}

discretionary governance - symbolic capital - status - secrecy - selection 
You remember $\mathrm{CoP}_{15}$ in Copenhagen? How everybody saw that as a failure? Well, one week later, all the key protagonists, apart from Obama, met in Davos. Without the political pressure. They met without any particular agenda. It was decompression. And our role? We, as organizers, pursue no particular agenda, but we provide space. And, after that meeting, Calderon suggested to get a move on with what later became the Cancun Agreement. At the top level, there is an increasing demand for this kind of space. It works as decompression. Here, it is possible to say things that can't be said at top meetings.

PAUL RICHARDSON, managing director, World Economic Forum

\section{$1 \quad$ Introduction 1}

Private actors have long been acknowledged as relevant participants in the field of global governance studies. ${ }^{2}$ They are commonly seen as providing different avenues for participation in and complementing international organizations (IOs) by being accountable to a broader set of constituencies. Yet they have also been seen as problematic because their impact often escapes monitoring and accountability to the public. ${ }^{3}$ The issues of transparency and accountability are further complicated when organizations that are sponsored by corporate money-for example, think tanks, foundations, and advocacy groups-are gaining leverage on the global scene. ${ }^{4}$ Within this context, the World Economic Forum (hereafter, WEF or Forum) is of specific interest.

As a not-for-profit Swiss foundation with global reach, WEF builds on the exclusive funding of 1,00o large transnational corporations to shape the direction of globalization with one overarching ambition: to "improve the state of the world" as its slogan states. Measuring success in meeting its ambition is a futile exercise, as the organization has no external decisionmaking mandate, as that of a state-based IO. Thus, there is nothing to measure other than communication in various formats. Instead of pushing for binding decisions, WEF works with arranging meetings for a broader set of individuals and organizations within global governance, in the interest of getting them running with the

1 The funding for the research presented in this article was provided by the Swedish Research Council (\#2010-01847).

2 For example, Rosenau 1995; Bernstein and Cashore 2007; Stone 2008; Bäckstrand et al. 2017; Hanegraaff 2015 .

3 Abbot, Green, and Keohane 2016, 247-248.

4 Garsten and Sörbom 2017. 
ideas and interests of the Forum. As indicated in the introductory quotation by WEF's managing director, Paul Richardson, principal gains for the Forum are achieved when other actors use its ideas. As fragile and tenuous as this form of private governance is, the thousands of CEO s, heads of states, top-level managers from IOs, and the many others of the aspiring global elite that partake in WEF events speak to some form of ordering. Some of the propositions brought up in Davos, Dubai, Cape Town, Dalian, or wherever the organization decides to set up its events are acted on by the very same partakers but in other contexts.

Drawing on ethnographic data, we address two questions: What characterizes this delicate form of ordering? And how may its results be of consequence for other organizations in broader society? In response, we introduce the term discretionary governance - a set of discreet practices based on the organizer's judgment, in ways that escape established democratic controls. At the core, this type of governance relies on the interest of each participant and that of the organizer to be recognized as a significant player in global policy and politics. Discretionary governance operates by way of careful selection processes, built largely on secrecy and with the attractive allure of high status on the global scene. For those who are chosen and meet WEF's evaluations, participation means at least temporary elevation to the crème de la crème of global governance.

Discretionary governance produces social ordering in a precarious, but specific, way. By presenting how selection, secrecy, and status form key components of this ordering, we disclose how they can be of consequence for WEF and other actors. Selection, in combination with practices of secrecy, contributes to status elevation of chosen individuals and organizations. On them is bestowed a symbolic capital that is practical and possibly profitable in the world of global governance. In the analysis of this tenuous ordering, we take inspiration from Thomas Weiss Weiss and Rorden Wilkinson, who encourage scholars in the field "to investigate the myriad ways that power is exercised" within the system of global governance. ${ }^{5}$ We suggest that by way of discretionary governance processes, the Forum succeeds in distributing its visions, which compete with other (possible) visions. This implies the exercise of a subtle, soft form of ordering based on the ability to shape preferences of others through appeal and attraction, rather than force or a state-based mandate. ${ }^{6}$

Empirically, we make use of data from our four years of on-and-off ethnographic fieldwork at WEF events and headquarters. Our quest through these

5 Weiss and Wilkinson 2014, 207.

6 Cf. Guzzini 2004; Nye 2008. 
years was to gain insights into WEF practices in the interest of understanding its role in global governance, some that are undertaken in plain view and some that are intentionally hidden. We wish to demonstrate and interpret the layers of practices, organizing, and meaning making of WEF and its participants. Our material comprises transcriptions of participant and nonparticipant observations, formal and informal conversations undertaken in and around WEF meetings in Cape Town, Davos (from three consecutive years), Dubai, and Istanbul, and at WEF headquarters in Cologny, outside of Geneva. All in all, our data are based on eighty days of observations and seventy interviews with WEF staff, ranging from forty-five to ninety minutes, twenty-five of which were recorded and later transcribed. Some interviews were semistructured, and others were more conversational in character. Several people were interviewed two or three times. With the exception of Klaus Schwab, founder of WEF (whom we interviewed twice), the identities of all informants are confidential. Original names of individuals, organizations, and corporations have been altered, along with their titles, nationality, and line of work. We have not usually altered gender, age, and relationship to WEF, however, to provide a better picture of participants and staff.

In the next part of the article, we introduce the concept of discretionary governance and how it may shed light on the attempts of ordering undertaken by the Forum. We then present WEF as an organization and earlier research on the topic of private actors in global governance. In the following section, we present key components of discretionary governance - selection, secrecy, and status - and how WEF uses them in the interest of promoting its visions for the world. The last part of the article summarizes our findings, advocating discretion as a key concept for understanding this form of private global governance more broadly.

\section{Discretionary Governance}

Drawing on the case of the World Economic Forum, we provide an account of the ways in which selection and secrecy beget status in the field of global governance, and how participants in WEF events and the organization itself try to secure the position of an actor to reckon with in this field - or at least to be seen as part of a global elite - thereby positioning WEF as an actor of consequence. Status is seen here a form of symbolic capital, which provides for credentials in the field of global governance. ${ }^{7}$ The reason actors (collectively

7 Cf. Bourdieu 1986, 1994; Cohen 2018. 
and individually) engage in these practices, is the $i_{\text {llusio }}^{8}$ of being someone of consequence in global governance. Having or providing symbolic capital is not an end in itself, however, but a way of being of consequence to others. A key aspect of Pierre Bourdieu's work on capital is an understanding of the conditions under which one form of capital could be converted into another. Thus, to understand how status as a form of capital may be used, we need to conceptualize how it can be put into motion. The important questions, therefore, are: How is this form of capital constructed and turned into a resource, and how may it be used?

Our answer begins with the recognition of the Latin root of the word discretion, discretio, sharing the same root as "distinction" and "discernment," implying the power to separate. ${ }^{9}$ Correspondingly, WEF draws on discretion as a capacity to discern those who are to be part of its "communities" and those who are not. These acts of discretion are distinguishers, by which WEF marks the person or organization as "worthy," and provides privileges accordingly. Bourdieu noted in Distinction that social actors distinguish "themselves by the distinctions they make." ${ }^{10}$ WEF accomplishes this feat by seeking out and elevating those who are invited to participate as the "best companies" and the "best brains of the world," while closing its doors to other aspirants and to prying eyes.

In tandem with the separating dimension of discretion, the term also has a connotation of concealing, and at times revealing, potentially important information-the second component of discretionary governance practices. As Georg Simmel explained, the performance of discretion is a social practice not merely based on the ability to keep secrets, but also on knowing how much to say to whom in which context. ${ }^{11}$ In the case of private global governance in the hands of WEF and its invitees, this ability entails a dynamic interplay of secrecy and openness. As WEF is a private foundation, it has vast degrees of freedom to decide what should be done in a given situation without referring to protocol. Thus, WEF can freely choose what to make public and what to keep hidden. In this way, WEF may orchestrate a careful balance between concealment and openness.

The concept of discretionary governance has been used by other scholars within the social sciences. ${ }^{12}$ Researchers have noted the often authoritarian and

\footnotetext{
$8 \quad$ Bourdieu 1996.

$9 \quad$ Mahmud 2012, 430.

10 Bourdieu 1984, 6.

11 Simmel 1906: 466.

12 For example, Gomez 2014; Hagendijk and Irwin 2006; Robison 2015.
} 
partly concealed dimensions of this form of governance, especially related to market practices, but have largely left the concept of discretion unattended. Anthropologist Lilith Mahmud departs from the very notion of "discretion," however, in her analysis of Italian Freemasonry, in demonstrating how discretion can be a key feature of the everyday practice of an organization which, just like WEF, is secluded, yet openly existing. ${ }^{13}$ In the world of Freemasonry, discretion is a norm that becomes an embodied disposition over time, allowing its members to assert their belonging in a community of initiates, lifted to a specific position of asserted uniqueness, while simultaneously allowing them to shield themselves from the intrusive gaze of the media and law enforcement. ${ }^{14}$ The practice of discretion among the Italian Freemasons also entailed the careful balancing of concealments and revelations characteristic of discretion, which also introduces an aura of prestige - an "adornment" of symbolic capital - that made the lodges appear elitist precisely because of their secrecy. Similarly, discretion is a way for WEF to assert its community to the inside and outside world and to deter attempts to intrude and to question. Discretion is both a key competence for participants at Forum events and a condition of the events that enable WEF actorhood in global governance. As such, discretion has a double meaning and origin: it is based on the judgment of WEF to discern what and who is relevant in global governance, and it relies on the capacity of its participants to exercise a degree of secrecy with respect to discussions at WEF meetings, its main consequence being the rendering of a sense of exclusiveness and nobility to WEF and its invitees.

Although significant contributions have been made with regard to how global governance is constituted and shaped in and by practices, ${ }^{15}$ the phenomenon is not yet sufficiently described and conceptualized; this especially goes to practices of discretion in private global governance. In line with Vincent Pouliot, we argue that the structural perspective and personal traits perspective that are common in the field of international relations studies have pushed researchers to describe organizational entities, while underplaying the role of practices and relationships, and thereby underplaying discretion and discreteness. ${ }^{16}$ If we are interested in understanding how a Swiss foundation, such as WEF, can play a consequential role in global governance and policymaking, the essentialist ontology can provide only half the picture. In addition, we need

\footnotetext{
13 Mahmud 2014.

14 Mahmud 2014, 17.

15 See, for instance, Neumann 2002; Best and Gheciu 2014; Pouliot 2016.

16 For an overview of research in the field of global governance that departs from an interest in practices, see Pouliot 2016; Pouliot and Thérien 2018.
} 
to be attentive to relations of force and meaning, asking questions about how these relations are enacted in practice. Knowledge about the way discreet practices amount to governance and acts of consequence requires development. The concept of discretionary governance is intended as a contribution toward this end.

Hence, discretionary governance is based on practices, as an ongoing series of practical activities bringing people together and constructing social order. ${ }^{17}$ In the WEF case the practices of selection, secrecy, and status are parts of the establishment and shaping of this social order-a fragile and precarious order that may often fail, yet persists. Simultaneously, these practices communicate the priorities of the organization-about what to go forward with, what to avoid, and who is to be recognized as an actor or in the field of global governance. For instance, when WEF staff decide on such topics as who will participate in an event or when communicating on what risks to avoid, it not only informs and articulates its interests and the reasons for those interests. In a constitutive move, it also communicates understandings of what and whom are and are not important, pivotal, and in focus - understandings that may be of consequence for later choices of other actors when they decide on whom to invite, what to discuss, and so forth.

One key ramification of this notion of governance is that it is based on attempts to be of consequence to others. There are few certainties in relation to the outcomes of this form of organizing. Thus, the difference that WEF may or may not introduce is observable only in later choices by other actors, a fact that contributes to the fundamental uncertainty that surrounds WEF. This is also the foundation for the truly relational character of governance in the hands of WEF. The consequences that may be induced by WEF are always dependent on how well it is able to cultivate relationships with others and motivate them to go forward.

We suggest that this form of unstable, and in terms of outcomes uncertain, but still observable ordering, is also relevant for understanding other private global governance actors, especially those living off corporate funding. The organizational model chosen by WEF, to have corporations essentially funding the organization by becoming members, may be seen as an extreme case, compared to, say, the Bilderberg Group and the Trilateral Commission, which have not opted for paying members. As an extreme case, however, it is rich in depth and width of information. By presenting this fragile, yet potentially significant, form of governance with global sway, we wish to contribute to the insight of

17 Cf. Giddens 1976, 81. 
global governance scholars whose interests are moving away "from formal rules and toward informal patterns that often pass under the scholarly radar."18 This issue is especially salient because governance, as has been convincingly argued for and demonstrated, is not primarily about rules, but about informal practices, ${ }^{19}$ by which "it is never clear who is exercising power on behalf of whom."20

\section{3 The World Economic Forum: An Answer to a Call}

In spite of its spectacular, potent media image, WEF is a small, lean organization, with no formal or legal mandate in international policymaking. Established in 1971 as a nonprofit foundation based in Geneva, Switzerland, it aims to provide an alternative to established IOs. Much of what we see today, in relation to the discretionary governance it employs, can be traced back to its origin. It started in Davos as a secluded event established primarily for the European industrial elite, who spoke of "the Spirit of Davos" and its informality. Also, at its start, it had the advantage of being under the patronage of the European Commission and European industrial associations. Only two years later, however, Klaus Schwab, founding CEO and chairman, decided to cut loose from the Commission, and since 1974 a number of politicians have been invited to its events in accordance with his idea of "multi-stakeholder meetings." ${ }^{21} \mathrm{WEF}$ positions itself as a response to gaps between national, transnational, and international authority structures laid bare by intensified globalization. As Klaus Schwab expressed it when we met for an interview in Geneva in 2013, "The World Economic Forum is a response to a need. We were not mandated by anybody. We created a response to a clear need in the international governance system."

In this context, WEF leadership staff described how the UN is too inert, too slow to set change into motion, and too exclusive in its membership, resting on nation-states and failing to include the voices of corporations and other organized communities. ${ }^{22} \mathrm{WEF}$ was created as a remedy to these pitfalls, offering a platform for leaders of government, business, and civil society to join forces in making the world a better place.

\footnotetext{
18 Pouliot and Thérien 2018, 92.

19 Finkelstein 1995; Dingwerth and Pattberg 2006; Weiss and Wilkinson 2018.

20 Slaughter 2004, 4.

21 Pigman 2007, 26.

22 WEF leadership staff, interviewed by the authors, Cologny, March 2013.
} 
WEF has approximately 650 employees located at its headquarters in Cologny outside of Geneva and in meagerly staffed regional offices in Beijing, New York, San Francisco, and Tokyo. Plans exist for more regional offices. ${ }^{23}$ The 1,0oo companies, called "members" and "partners," that fund the organization are some of the largest and most highly ranked companies in their fields. The highest governing body of WEF is the Foundation Board, comprising a smaller number of highly influential persons, some of whom are chosen from the funders. In 2015, the Forum was formally recognized as an international organization ("other international body") by the Swiss government, and now describes itself as "the International Organization for Public-Private Cooperation." ${ }^{24}$

The funding base reflects the leverage that can be gained from attracting corporate funding and organizing corporate interest into a larger whole, a process that is part of global governance. ${ }^{25}$ We see WEF and the environment it has built around itself as an interorganizational arrangement, comprising multiple actors, spanning sectors, but based on individuals who (at times) work together to influence, shape, and monitor public and business choices.

A key condition of WEF as an organization is that, like any private global governance actor, it is bare with regard to state-based legitimacy. In the Weberian sense, legitimacy refers to having the authority to act in some specific capacity. ${ }^{26}$ State-based organizations are rendered legitimate because of their mandate, whereas private organizations must construct a private form of legitimacy. The fundamental asset for WEF's legitimacy is people. It is essentially the influence and recognition of WEF by individuals who render legitimacy to the organization, and it is the agency of these individuals that provides WEF with an agentic capacity beyond what it would possess by itself. It is noteworthy, therefore, that in all WEF activities, representation is fundamentally wanting, and there is no mechanism for representation. Even in relation to its "members," the 1,ooo funding corporations, it is the individual who is invited and participates in deliberations. Even heads of governments and IOs or CEOs from funding companies who come to do business in the interest of their company are there because they are important to WEF as individuals, not as representatives of other bodies.

\footnotetext{
23 Schwab 2015.

24 Federal Department of Foreign Affairs, 2015, o1, 23.

25 Pigman 2007; Garsten and Sörbom 2018.

26 Weber 1947.
} 
The social order that WEF is attempting, and to some extent succeeds in setting, around itself is based partly on distinguishing and thereby elevating the "right" invitees (from funders and more broadly) to become the thought leaders with which the organization prides itself in partnering. As Pierre Bourdieu noted in his analysis on distinctions, ${ }^{27}$ such processes function simultaneously as a system of power relations and a symbolic system through which minute distinctions become the basis for social judgment.

WEF staff in Cologny described how identification of the right person for each panel, community, or project absorbs most of their time at headquarters. As was told to us by WEF staff, there is a "constant haggling" on whom to invite, even from funders because, when they participate in WEF deliberations, they do so as individuals. These invitees are the key resource for the organization and candidates are discerned through a lengthy process. Not only are they the ones that indicate to the world what WEF is, they are also the ones to do real work of WEF organizing-spreading its discourse and diffusing its ideas. Invitees must therefore be perfect not only for the role they are to play, but for their ability to match and communicate WEF's ideas of global citizenship. So, the organization screens, picks, and evaluates the suitability of each potential invitee which, in the Davos case, amounts to circa 3,500 participants. The screening process may take a year and involves a check of the potential invitee's background: education, work experience, expertise, credentials, credibility, and integrity. Noteworthy is that the majority of participants tend to be men, coming from Europe and the United States with an education from the ten highest-ranked universities in the world. This was clear when we read and counted the content of curriculum vitæ from more than 4,500 participants over a number of years. ${ }^{28}$ Paola Pakulsky, manager of one of the in-house departments at Cologny headquarters, is in charge specifically of the process of due diligence. She explained the role her team plays in setting up events, working under the motto of finding the "right person at the right time, in the right agenda." However, telling people that they cannot come is a taxing task as well. As junior manager, Daniel Berg, told us, "You would not believe the effort we have to put in telling people that they can't come-much more [effort] than saying that people can come." And those contacting WEF request-

\footnotetext{
27 Bourdieu 1984.

28 Based on participant CVs, published at the WEF website, of all twenty-one external Forum events between 2011 and $2013(N=3,790)$, and a sample of participants from the 2017 annual meeting $(n=996)$ (Garsten and Sörbom 2018, 236-239).
} 
ing invitations allegedly range from heads of states to CEOs, journalists, and researchers-just like the two of us.

During our fieldwork, when participating in events and hanging around in the WEF-designated "networking areas," many invitees conveyed to us the exhilarating sense of elevation from having been invited and being present where the action is, among the selected few. Matthew Tong, a professor of international relations from Oxford, dubbed by the Forum as one of the world's best brains and part of what it calls "its brain trust," told us that he could not believe it when the invitation to be part of a meeting in Dubai arrived. "I thought someone was playing a trick on me, so I called Cologny and asked them to call me." Amir Shihadeh, curator of the Amman hub of the Young Global Shapers, a young people's community organized by WEF, conveyed something similar with regard to the Davos event: "Literally, get ready for the best experience in your life! As a Global Shaper, the World Economic Forum's Annual Meeting in Davos, Switzerland is the most amazing, passionate, awe-inspiring, phenomenal, and influential event you'll ever attend in your life."29

The selection is, however, a never-ending process because having made it to one WEF event, the horizon opens up for even stronger credentials by being reinvited. Therefore, with one's first selection comes the anxiety of being thrown out, losing the status and privilege of belonging in "the WEF community." Accordingly, the position of an invitee can be described as aspirational; constantly looking out for more invitations. And although WEF tends to look into its rolodex of former invitees to find names for new occasions, being reinvited is contingent on one's performance and WEF's priorities. Every performance is evaluated, foremost by the collection of information from other participants and colleagues. In the following quotation, Diana Gordon, a higherlevel manager in Cologny, talking on these evaluations, somewhat ambiguously describes WEF's criteria in considering its reinvitations:

[We do] not regularly [get disappointed by invitees], but there are always people that we think, like: "Okay, well that maybe served its purpose for that particular ... but it's not someone we would necessarily want to continue to re-engage with." It could be that ... they're brilliant, all of them, brilliant people, it's just that, you know, how available were they in the preparations? It's one aspect that we really have to take into consideration. And how willing were they to really understand what the mission and the vision of the Forum is, and not just bring their own idea to the 
table? How good are they, and not just. ... Obviously, they are amazing thought leaders ... but how well are they able to articulate their ideas on a panel?

Apparently, Ms Gordon was a bit cautious when describing what works and what does not. She did not want to discredit any former invitees because "they are all brilliant thought leaders." Yet as she notes, a major criterion for being reinvited is an understanding of the "mission and vision of the Forum." It is not enough to be brilliant; one must also fit WEF's views on what is important content and format, and live up to its expectations. Spending some time in and around the events, we soon realized that participants are aware of the continuous evaluation and tend to avoid criticism. One of the participants at a WEF meeting, Dr Peel, who held a leadership position in a prominent British policy institute and was highly esteemed by the Forum, advised us in lowered tones: "You have to be careful. There are many who want to hide things, since it's so important for them to come back." Interestingly, or alarmingly, even accredited journalists know that they may not be accepted next time around and may act accordingly. Beatrice Kallis from a major European media house, described in detail for us how her reporting was monitored by WEF's staff, and she swiftly told us that she had no intention of annoying them by reporting something that would not be appreciated.

Yet WEF does not confer to either the outside world or to participants that invitees are replaceable or selected. Rather, selections are communicated in self-evident terms, as these are the most brilliant and prominent thought leaders. As such, the successful invitee may, momentarily, be part of the global nobility, dubbed as worthy by WEF.

The second component of the discretionary governance of WEF is secrecy, which contributes to a mysterious and alluring connotation to the name of WEF. As WEF communications Mr. Luck told us over coffee in Dubai, "The WEF is a shy organization. It is not interested in displaying its victories." This type of euphemism reflects the self-image of WEF. It implies that WEF, to its own mind, has been able to construct itself as an actor of consequence in global governance, reminding one of the Cicero quote "esse quam videri" (to be, rather than to be seen). Within the WEF, discretion requires of both organizers and invitees the participation in a heuristic set of secrecy practices that, while effectively concealing important knowledge from view, also makes it possible for 
that same knowledge to be shared among members of a selected group. In turn, it is the ability to participate in these practices of secrecy that confirms the experience of belonging in the group, ${ }^{30}$ and renders the half-secret events an aura of prestige and appeal.

In practice, secrecy entails the ongoing processes of intentional concealment of information by WEF and by actors involved in its activities. ${ }^{31}$ Much of what happens at a WEF meeting is set outside of the public limelight. There is the official, public program and the private, unofficial programs of invitees and staff. At the Davos meetings, for example, the public may see the official program broadcast from the convention center. Then, there is the private program of each invitee, built on private encounters that WEF arranges for each individual, which, in turn, may be punctuated by fully separated sessions that are not known to Forum staff.

In Davos, we observed a secret lunch discussion at a hotel outside the Davos conference center. It was an "invites only" event, as termed in WEF lingo, thus not announced in the official program and known only to individual participants who were privately invited, and organizers. We could observe the lunch, in spite of not being invites, because WEF staff for some reason decided "to look the other way," as they phrased it. The lunch offered the possibility for a number of persons to meet and discuss the question of "what to do with the Arctic." The context was the Arctic ice melt, which provides business opportunities for logistics and oil companies, among others. Yet uncertainty in relation to the legal standing of the area made investments risky.

Participating at the lunch were the prime minister of a Nordic country, a few members of the Arctic Council, one scientist, and CEO s or top managers from a number of corporations interested in the area. A few of the participants were offered the opportunity of introducing their views on the topic while the others were eating. In this closed setting, the attending prime minister told the corporate leaders that they were welcome to the Arctic, as long as they followed existing regulations. "These resources will be exploited," he stressed, "but it needs to be done in a respectful way." The CEO from a European oil company, on the other hand, talked about the challenge and the importance of establishing guidelines for corporations-perhaps headed by WEF? The scientist was also invited to speak, and she rose to inspire participants to think of the environmental consequences.

30 Cf. Mahmud 2012, 43 o.

31 Cf. Costas and Grey 2014, 2016 on organizational secrecy. 
An essential point of the Arctic lunch, and WEF's secluded events at large, is that all participants need to recognize and follow the Chatham House Rule: "What is said in the room stays in the room." Thus, participants may make use of what is said at events; in fact, WEF promotes their doing so. But they need to know how to do it discretely - knowing when to talk and when to keep a secret. That is part of following the mission and the vision of the Forum, and a basic knowledge of discretion. Lacking this competence threatens the prospects of coming back.

But secrecy within WEF is not merely a responsibility of participants. The organization itself is committed to holding its events so that critical topics can be discussed without media attention or other forms of leakage. Toward this end, one critical dimension is the continuous staging of the invisible boundaries of inside and outside, and the perception of an impenetrable core, in practice constructing "a safe space," as WEF staff call it. Therefore, WEF takes great care to protect its invitees from unnecessary exposure. Every hotel room in Davos during the WEF week is prebooked so that only invitees may stay. Since the early 200os, activists have commonly not been allowed to come to Davos during the week. Streets are guarded by some 5,00o military police, patrolling streets and sky, with snipers posted on rooftops. Within event arenas, various types of meetings are surrounded by varying degrees of protection and secrecy, and the proper degree of exclusion is a constant concern. Meeting spaces are differentially secluded, depending on the topic and the access of participants. Media accreditation provides entrance to only public areas. In fact, the majority of the meeting does not take place in the areas to which journalists are admitted. The Arctic lunch, for instance, was not available to journalists.

As expressed in the quotation on $\mathrm{CoP}_{15}$ that opens this article, at WEF meetings it should be "possible to say things that cannot be said in top meetings." "Safe space" is here meant to protect not only lives, but also ideas. Secrecy, privacy, and closed doors are therefore more important to WEF than are norms of transparency and accountability. Even so, the Forum is not a secret society. Rather, WEF knows how to manage secrecy discreetly and how to use it in the interests of the organization. Broadcasting events from the Davos meeting, for instance, tells the world of how open WEF intends to be. What is not on display is the invitation-only part of the program. The internet displays are, in some respects, mystifiers posing as demystifiers. ${ }^{32}$ 
Simmel aptly described the essence of human interaction as "conditioned by the capacity to speak," but "shaped by the capacity to be silent." ${ }^{33}$ By knowing when to speak and when not to speak, an actor can manipulate and even dominate relationships. In the case of WEF, the interplay between open and closed also forms part of its euphemistic play with silence and speech. Moreover, as Simmel explained, secrets function by setting barriers between actors. ${ }^{34}$ The veil of secrecy, in combination with its wall of security, produces the same type of interest in the organization as do the secret societies described by Simmel.

Status

The careful selection process and the many secrecy practices outlined here are vital for conferring onto WEF invitees a sense of being elevated above the common person and given status distinction, while these high-end invitees convey to the outside world a sense of WEF's importance. The process works as a symbolic system, in which distinctions become the basis for social understandings. These interactions construct an effect similar to what philosopher Ian Hacking terms "the looping effect." 35 When someone is classified in a certain way, other relevant actors can use that classification. In a similar vein, being among those chosen by WEF becomes a classification that vests the invitee-and the Forum-with status.

In this context, the badge of entrance is a clear marker of status. The badge comes in different color codes and designs, the white hologram badge signifying the highest level of admission and exclusivity. Technically, their purpose is to signify to security staff who is to be let into which type of meeting. It also signals status between invitees, who soon learn the implications behind the various badges. For instance, invitees with the common blue badge are higher ranking than the purple given to lower staff, but have less access to the compound compared to those given the hologram. Generally, differences are due to having paid more as a funder, or holding office in states, or IO s considered of importance to the WEF. Thus, as important as is this signal of inclusion, so also is the signal of exclusion - of being left out.

The status elevation of having been selected by WEF confers a form of symbolic capital that may be drawn on as a resource in various contexts, and in

33 See Wolff 1964, 349 .

34 Simmel 19o6, 466.

35 Hacking 2006. 
various ways. Olafur Gunnlaugson, from one of the larger corporate foundations in Scandinavia, with whom we met at Pizzeria Daiano inside the Davos conference compound, explained the value of being there: "If you're not here, you don't exist." At an ontological level, being invited, even as a funder, is being defined as part of the world of global business or global governance, and a way of demonstrating one's importance in the field. And, as Peter Bond, a toplevel director at one of the long-standing WEF funding corporations, described, being selected may "create value" in the broad sense of the term. The status of being a WEF funder may not be instantly rewarding from a market point of view. In the long run, however, he reasoned, being let into conversations with other corporate and political leaders of similar status meant that one was given the position to shape political discussions of possible value to his corporation. Even political leaders may find the invitation profitable. As Ronald Parkinson, minister of finance from a European country, conveyed to us, being a WEF invitee "is invaluable for networking." And as WEF staff members told us, it is not uncommon at WEF to be contacted by heads of governments who want an invitation. The opportunity to participate allows them to show a "good face" to their public, as a leader chosen to be among the other "world leaders," while at the same time having the opportunity to talk to peers in a "safe space."

Recognition by WEF can also be a door opener for more direct value creation. In Istanbul, we met with Izmir Ballantz, who told us of the many business meetings he could arrange when accepted to a WEF event. The symbolic capital of the WEF invitation is here drawn on for face-to-face encounters and unique networking opportunities. Laurence Moritz from a large nongovernmental organization, who had participated in the Dubai brain trust event several times, described how after his first meeting he came back having secured million-dollar funding for his organization. "No wonder," he said, "I keep wanting to come back." Ms. Doe, a senior executive at a high-tech company in Silicon Valley, who traveled a great distance to the Dubai event, described in a coffee break the reason for her to be there as entirely "about networking and seeking business partnerships."

Status is truly a resource in an economy of connections here-valuable for one's own CV and working relations. ${ }^{36}$ With Max Weber, we say that status"the social estimation of honour"-is essentially based on recognition, distance, and exclusiveness. By "setting themselves apart by means of any other characteristics and badges ... all these elements usurp status honour." ${ }^{37}$ In so

\footnotetext{
$36 \quad$ Garsten 2015 .
}

37 Weber 1947, 138. 
doing, individuals may obtain the right to be part of a status group, however informally which, in turn, may be the basis for influential interactions of a political or economic character. One may indeed view the invitees as subjects involved in a struggle for recognition, accumulating relationships and experiences perceived to be worthy and meaningful. They are motivated by stakes perceived to be worthy of struggle; they see the investment of their time, effort, and emotion as a valuable endeavor; and they are committed to reaping the rewards of their efforts as a worthy goal..$^{38}$ In other words, they are invested in the illusio of WEF as a point of gravity or, in the words of Pierre Bourdieu and Loïc Wacquant, "taken in and by the game."39

\section{7 Conclusion: Discreet Governance beyond WEF}

WEF attempts to influence future organizing and decisions, and at times succeeds - a capability it achieves by deploying other actors around the world. Its capability is strongly related to the three types of practices comprising its discretionary governance: selection, secrecy, and status. This form of governance is quiet, prudent, and restrained. It is based on the discretion of the Forum acting in its own interest of being a powerful actor in global governance, and on the discretion of its funders and invitees. In so doing, it also contributes to proposing what may later become an item on a formal agenda and the foundation for decisions and practices of other influential organizations. The noteworthy point about its standing in private global governance is its relational character. By way of its extended network, agency may flow in and between WEF and its participants and partner organizations in dynamic ways. This is truly a case of borrowing agency from others and extending agency from oneself onto others. In this manner, WEF may become an actor in the field of global governance with influence through, and on behalf of, other actors who make ideas travel..$^{40}$

Given later developments in global governance, with more of the sort of private and exclusive organizations that WEF exemplifies, we have strong reasons to believe that discretionary governance is of increasing importance, with significant implications for the ways in which nation-states, corporations, and nongovernmental organizations construe global governance activities. Together, these actors construe a world system of multilevel and partly

38 See Threadgold 2019, 39 .

39 Bourdieu and Wacquant 1992, 116.

40 Cf. Czarniawska and Sévon 2005. 
private governance networks, with operating procedures that are often beyond the control of any single actor. We are seeing the development of what Guilio Gallarotti called a "hazy power space."41 Along with Gallarotti, we contend that national and established forms of power have become transformed in ways that have made it far more difficult to gauge and consequently manage, which necessitates new approaches to the study of governance and its changing role in world politics. The study of global networks of informal capabilities and of transnational, discretionary forms of governance is still underdeveloped relative to its importance in international politics. ${ }^{42}$ The conventional visions and models of state power are poorly suited to understanding modern global governance systems built on discretion and symbolic capital.

We have not raised normative matters in the functioning of discretionary governance. It is clear, however, that organizations such as WEF-the Bilderberg Group and European Roundtable of Industrialists, for instance, but also newcomers such as Brilliant Minds, St. Petersburg International Economic Forum, MISK Global Forum, and Google Camp-are constructing a situation in which they have vast freedom in dealing with global matters without referring to protocol. From this position, these organizations can freely choose whom to invite as participants in their communities, what to negotiate, and what to make public. Although these practices may be intended for "improving the state of the world," as WEF would have it, issues of transparency, representation, and accountability are acute. They need to be addressed not only in further research, but within the same organizational and political practices.

\section{Bibliography}

Abbott, Kenneth, Jessica Green, and Robert Keohane. "Organizational Ecology and Institutional Change in Global Governance." International Organization 70 (2) (2016), 247-277.

Bäckstrand, Karin, Jonathan W. Kuyper, Björn-Ola Linnér, and Eva Lövbrand. "Nonstate Actors in Global Climate Governance: From Copenhagen to Paris and beyond." Environmental Politics 26 (4) (2017), 561-579.

Baldwin, David A. "Power and International Relations." In Handbook of International Relations, 2nd ed., eds. Walter Carlsnaes, Thomas Risse, and Beth Simmons (London: Sage, 2013), 273-297.

41 Gallarotti 2015, 247.

42 Willets 2011; Baldwin 2013; Gallarotti 2015; Barnett 2016; Hale 2020. 
Barnett, Michael. "Expertise, Accountability, and Global Governance: The View from Paternalism." Regulation and Governance 10 (2016), 134-148.

Bernstein, Steven, and Benjamin Cashore. "Can Non-state Global Governance Be Legitimate? An Analytical Framework." Regulation and Governance 1 (4) (2007), 347371.

Best, Jacqueline, and Alexandra Gheciu, eds. The Return of the Public in Global Governance (Cambridge: Cambridge University Press, 2014).

Bourdieu, Pierre. Distinction: A Social Critique of the Judgment of Taste (London: Routledge, 1984).

Bourdieu, Pierre. "The Forms of Capital." In Handbook of Theory and Research for the Sociology of Education, ed. J. Richardson (New York: Greenwood, 1986), 241-258.

Bourdieu, Pierre. The Field of Cultural Production (New York: Columbia University Press, 1994).

Bourdieu, Pierre. The Rules of Art: Genesis and Structure of the Literary Field (Cambridge: Polity Press, 1996).

Bourdieu, Pierre, and Loïc Wacquant. Invitation to a Reflexive Sociology (Chicago: University of Chicago Press, 1992).

Cohen, Antonin. "Pierre Bourdieu and International Relations." In The Oxford Handbook of Pierre Bourdieu, eds. Tom Medvetz and Jeffrey J. Sallaz (Oxford: Oxford University Press, 2018), 225-258.

Costas, Jana, and Christopher Grey. "Bringing Secrecy into the Open: Towards a Theorization of the Social Processes of Organizational Secrecy." Organization Studies (35) (10) (2014), 1423-1447.

Costas, Jana, and Christopher Grey. Secrecy and Work: The Hidden Architecture of Organizational Life (Stanford: Stanford University Press, 2016).

Czarniawska, Barbara, and Guje Sévon. Global Ideas: How Ideas, Objects, and Practices Travel in the Global Economy (Copenhagen: Liber and Copenhagen Business School Press, 2005).

Department of Foreign Affairs. Agreement Signed with the WEF. 2015. www.admin.ch/ gov/en/start/dokumentation/medienmitteilungen.msg-id-55987.html

Dingwerth, Klaus, and Philipp Pattberg. "Global Governance as a Perspective on World Politics.” Global Governance12 (2) (2006), 185-203.

Finkelstein, Lawrence. "What Is Global Governance?" Global Governance 1 (3) (1995), 367-372.

Gallarotti, Giulio M. “Smart Power: Definitions, Importance, and Effectiveness." Journal of Strategic Studies 38 (3) (2015), 245-281.

Garsten, Christina. "Global Swirl at Dupont Circle: Think Tanks, Connectivity, and the Making of 'the Global." In Anthropology Now and Next, eds. Thomas Hylland Eriksen, Christina Garsten, and Shalini Randeria (London: Berghahn Books, 2015), 709 . 
Garsten, Christina, and Adrienne Sörbom. Power, Policy and Profit: Corporate Engagement in Politics and Governance (Cheltenham: Edward Elgar, 2017).

Garsten, Christina, and Adrienne Sörbom. Discreet Power: How the World Economic Forum Shapes Market Agendas (Stanford: Stanford University Press, 2018).

Giddens, Anthony. New Rules of Sociological Method (London: Hutchinson, 1976).

Gomez, Pierre-Yves. "On the Discretionary Power of Top-Executives: Evolution of the Theoretical Foundations." International Studies of Management and Organizations 34 (2) (2014), 37-62.

Guzzini, Stefano. "The Concept of Power: A Constructivist Analysis." Millennium:Journal of International Studies33 (2004), 495-521.

Hacking, Ian. "Kinds of People: Moving Targets." British Academy Lecture, 2006. https:// britishacademy.universitypressscholarship.com/view/10.5871/bacad/978019726424 9.oo1.ooo1/upso-978o197264249-chapter-10.

Hagendijk, Rob, and Allan Irwin. "Public Deliberation and Governance: Engaging with Science and Technology in Europe." Minerva 44 (2006), 167-184.

Hale, Thomas. "Transnational Actors and Transnational Governance in Global Environmental Politics." Annual Review of Political Science 23 (2020), 203-22O.

Hanegraaff, Marcel. "Interest Groups at Transnational Negotiation Conferences: Goal, Strategies, Interactions and Influence." Global Governance 21 (4) (2015), 599620.

Mahmud, Lilith. " "The World is a Forest of Symbols": Italian Freemasonry and the Practice of Discretion." American Ethnologist, 39 (2) (2012), 425-438.

Mahmud, Lilith. The Brotherhood of Freemason Sisters: Gender, Secrecy and Fraternity in Italian Masonic Lodges (Chicago: Chicago University Press, 2014).

Neumann, Iver B. "Returning Practice to the Linguistic Turn: The Case of Diplomacy." Millennium: Journal of International Studies 31 (3) (2002), 627-651.

Nye, Joseph. "Public Diplomacy and Soft Power." Annals of the American Academy of Political Science 616 (2008), 94-109.

Pigman, Geoffrey. The World Economic Forum: A Multi-Stakeholder Approach to Global Governance (London: Routledge, 2007).

Pouliot, Vincent. International Pecking Orders: The Politics and Practice of Multilateral Diplomacy (Cambridge: Cambridge University Press, 2016).

Pouliot, Vincent, and Jean-Philipp Thérien. "Global Governance in Practice." Global Policy 9 (2) (2018), 16-172.

Robison, Richard. "Strange Bedfellows: Political Alliances in the Making of Neoliberal Governance." In Governance and the Depoliticization of Development, eds. Will Hout \& Richard Robison, (London: Routledge, 2015).15-28.

Rosenau, James. "Governance in the Twenty-First Century." Global Governance 1 (1) (1995), 1-43.

Schwab, Klaus. Visions 2020 (Cologny, Switzerland: World Economic Forum, 2015). 
Shihadeh, Amir. “Davos Best Practices and Tips.” Global Shapers Blog, 2015, January, 27. www.globalshapers.org/es/node/27592.

Simmel, George. "The Sociology of Secrets, and of Secret Societies." American Journal of Sociology 11 (1906), 441-498.

Slaughter, Anne-Marie. A New World Order (Princeton: Princeton University Press, 2004).

Stein, Howard. "Organizational Euphemism and the Cultural Mystification of Evil." Administrative Theory and Practice 20 (3) (1998), 346-357.

Stone, Diane. "Global Public Policy, Transnational Policy Communities, and Their Networks." Policy Studies Journal 36 (1) (2008), 19-38.

Threadgold, Steven. "Bourdieu is not a Determinist: Illusio, Aspiration, Reflexivity and Affect." International Perspectives on Theorizing Aspirations: Applying Bourdieu's Tools, eds. Gart Stahl, Derron Wallace \& Ciaran Burke. (London: Bloomsbury, 2019), 2-50.

Weber, Max. Theory of Social and Economic Organization. Edited by Talcott Parsons (New York: Free Press, 1947).

Weiss, Thomas, and Rorden Wilkinson. "Rethinking Global Governance? Complexity, Authority, Power, Change." International Studies Quarterly $5^{8}$ (2014), 207-215.

Weiss, Thomas, and Rorden Wilkinson. "The Globally Governed-Everyday Global Governance." Global Governance 24 (2) (2018), 193-210.

Willets, Peter. Non-governmental Organization in World Politics: The Construction of Global Governance (Abingdon: Routledge, 2011).

Wolff, Kurt. The Sociology of Georg Simmel (New York: Free Press of Glencoe, 1964). 